\title{
Pengaruh Konservatisme Dan Investment Opportunity Set (Ios) Terhadap Kualitas Laba Dengan Kepemilikan Manajerial Sebagai Pemoderasi
}

\author{
Putu Astri Yunita ${ }^{1}$ \\ Bambang Suprasto $\mathbf{H}^{2}$
}

${ }^{1}$ Fakultas Ekonomi dan Bisnis Universitas Udayana (Unud), Bali, Indonesia e-mail:putuastriyunita@gmail.comtelp: +62 8987410142

${ }^{2}$ Fakultas Ekonomi dan Bisnis Universitas Udayana (Unud), Bali, Indonesia

\begin{abstract}
ABSTRAK
Tujuan penelitian ini untuk mengetahui (1) pengaruh konservatisme terhadap kualitas laba, (2) pengaruh IOS terhadap kualitas laba, (3) kepemilikan manajerial memoderasi konservatisme terhadap kualitas laba, (4) kepemilikan manajerial memoderasi IOS terhadap kualitas laba. Populasi pada penelitian ini adalah perusahaan manufaktur yang terdaftar di Bursa Efek Indonesia periode pengamatan 2013-2015. Jumlah sampel penelitian ini adalah 63 perusahaan dengan 189 data amatan. Pengambilan sampel dalam penelitian ini menggunakan metode non probability dengan teknik purposive sampling. Teknik analisis data pada penelitian ini menggunakan moderated regression analysis (MRA). Hasil penelitian menunjukkan bahwa tingkat konservatisme berpengaruh positif terhadap kualitas laba, sedangkan IOS berpengaruh negatif terhadap kualitas laba. Penelitian ini tidak mampu membuktikan kepemilikan manajerial memoderasi pengaruh konservatisme dan IOS terhadap kualitas laba.

Kata Kunci: konservatisme, investment opportunity set, kualitas laba, kepemilikan manajerial
\end{abstract}

\begin{abstract}
The purpose of this study is to determine (1) the influence of conservatism on the quality of profit, (2) the effect of IOS on earnings quality, (3) managerial ownership moderate conservatism on earnings quality, (4) managerial ownership moderate IOS on earnings quality. The population in this study is a manufacturing company listed on the Indonesia Stock Exchange period of observation 2013-2015. The number of samples of this study is 63 companies with 189 observational data. Sampling in this research using non probability method with purposive sampling technique. Data analysis techniques in this study using moderated regression analysis (MRA). The results showed that conservatism had a positive effect on earnings quality, while IOS had negative effect to earnings quality. This study is unable to prove managerial ownership moderate the influence of conservatism and IOS on earnings quality

Keywords: conservatism, investment opportunity set, earnings quality, managerial ownership
\end{abstract}


Putu Astri Yunita dan Bambang Suprasto. Pengaruh...

\section{PENDAHULUAN}

Kualitas laba yang baik memiliki arti penting untuk stakeholder yang digunakan dalam pengambilan keputusan (Schipper dan Vincent, 2003). Menurut Bellovary et al. (2005), kualitas laba merupakan kemampuan laba pada saat menyajikan laba sebenarnya pada perusahaan dan membantu memprediksi laba mendatang yang mempertimbangkan stabilitas dan persistensi laba. Oleh karena itu, kualitas laba merupakan akurasi laba dalam menggambarkan kejadian-kejadian yang terdapat pada perusahaan dan sebagai alat prediktor laba pada periode mendatang. Salah satu kriteria laba tersebut dapat dikatakan berkualitas adalah rendahnya tingkat fluktuasi dari periode satu ke periode berikutnya. Laba dengan tingkat fkuktuasi yang rendah menjadi suatu tantangan yang berat bagi manajemen perusahaan karena terdapat banyak faktor yang dapat memengaruhi naik turunnya laba baik faktor dari luar maupun dari dalam perusahaan, sehingga tidak sedikit perusahaan yang memiliki laba dengan tingkat fluktuasi yang tinggi. Hal ini dapat kita lihat pada laporan keuangan perusahaan manufaktur yang terdaftar di www.idx.com dari tahun 2013 sampai tahun 2015, dimana berikut disajikan pada tabel beberapa perusahaan yang menyajikan laba dengan tingkat fluktuasi yang tinggi :

Tabel 1. Laba Perusahaan Manufaktur Periode 2013-2015 (Dalam ribuan rupiah)

\begin{tabular}{cccc}
\hline & Laba & Laba Periode & Laba Periode \\
Nama Perusahaan & Periode & 2014 & 2015 \\
& 2013 & & \\
\hline PT. Alakasa Industrindo Tbk & $(315)$ & 2,659 & 1,175 \\
PT. Asahimas Flat Glass Tbk & 338 & 458 & 341 \\
PT. Berlina Tbk & $(12,219)$ & 56,998 & $(7,159)$ \\
PT. Dwi Aneka Jaya Kemasindo Tbk & 68,043 & 90,592 & $(439,404)$ \\
PT. Delta Djakarta Tbk & 270,498 & 288,073 & 192,045 \\
\hline
\end{tabular}

Sumber: $\underline{w w w . i d x . c o m}$ 
Berdasarkan Tabel 1, dapat kita lihat bahwa terdapat beberapa perusahaan manufaktur di Indonesia yang memiliki laba dengan tingkat fluktuasi yang cukup tinggi sehingga akurasinya dipertanyakan serta sulit untuk memprediksi laba dimasa mendatang sehingga rawan terjadi kesalahan dalam pengambilan keputusan oleh pengguna laporan keuangan.

Laba umumnya memiliki arti selisih income terhadap biaya-biaya yang dikeluarkan. Adapun makna dari laba itu sendiri berdasarkan pada konsep mempertahankan kapital yaitu peningkatan kondisi ekonomi selama periode tertentu yang dinikmati oleh pemilik dengan mempertahankan kapital sebelumnya. Bandi (2009) menyatakan untuk menjadi informasi yang berguna, laba sebagai bagian dari laporan keuangan harus berkualitas. Pada Statement of Financial Accounting Concept (SFAC) No. 1 dijelaskan bahwa laba dapat membantu mengestimasi laba representatif dalam jangka panjang, memprediksi laba, dan menaksir risiko dalam investasi atau kredit. Kualitas laba memiliki dampak yang signifikan baik terhadap perusahaan, pihak investor dan kreditor karena kualitas laba pada suatu laporan keuangan menentukan kinerja perusahaan itu sendiri. Menurut Widjaja et al. (2011), kualitas laba perusahaan merupakan salah satu informasi penting yang tersedia untuk publik dan dapat digunakan investor untuk menilai perusahaan. Kualitas laba yang rendah mengganggu investor dan pengguna laporan keuangan lainnya sehingga dapat menyebabkan kesalahan alokasi modal (Schipper dan Vincent, 2003).

Menurut Francis et al. (2008), laba yang berkualitas terbagi menjadi dua kriteria dimana yang pertama yaitu pendekatan market based dan yang kedua yaitu 
Putu Astri Yunita dan Bambang Suprasto. Pengaruh...

accounting based. Pendekatan pertama pada sisi market based, laba akan berkualitas apabila bersifat relevan untuk mengambil keputusan serta tepat waktu dan pendekatan kedua pada sisi accounting based, laba akan berkualitas apabila bersifat persisten, tidak berfluktuatif serta memiliki kemampuan untuk memprediksi laba untuk tahun berikutnya. Penelitian yang dilakukan oleh Beijerink (2008) menemukan perbedaan yang signifikan pada kualitas laba yang menggunakan market based, relevansi belajar, dan ketepatan waktu laba dengan menggunakan US GAAP dan IFRS dimana penelitian tersebut menyatakan bahwa laba yang dilaporkan menggunakan IFRS memiliki tingkat relevansi dan ketepatan waktu laba yang tinggi daripada laba yang dilaporkan menggunakan US GAAP. Schipper dan Vincent (2003) mengelompokkan konstruk kualitas laba dan pengukurannya bedasarkan penentuan kualitas laba. Adapun penentuan kualitas laba tersebut berdasarkan: 1) Sifat runtun-waktu dari laba; 2) Karakteristik kualitatif dalam rerangka konseptual; 3) Hubungan laba-kas-akrual; 4) Keputusan implementasi

Beberapa riset terhadap kualitas laba telah dilaksanakan, seperti penelitian Lara (2009) yang menyatakan manipulasi akuntansi pada akuntansi akrual dan aktivitas riil yang menyimpang pada praktek normal mengurangi kualitas laba. Sutopo (2009) menjelaskan kualitas laba sebagai laba yang secara benar dan akurat menggambarkan profitabilitas operasional perusahaan.

Faktor lain yang mempengaruhi kualitas laba, salah satunya yakni konservatisme akuntansi. Menurut Basu (2009), konservatisme merupakan praktik yang mengurangi laba saat perusahaan menghadapi bad news dan tidak menaikkan 
laba pada saat perusahaan menghadapi good news. Perusahaan dengan tata kelola yang baik menggunakan konservatisme akuntansi untuk melindungi investor dengan memberikan informasi mengenai berita buruk (bad news) pada waktu yang sangat tepat (Lara et al. 2009). LaFond dan Watts (2008) menyebutkan bahwa akuntansi konservatif lebih baik diterapkan karena bisa mengurangi insentif dan kemampuan manajer dalam memanipulasi angka-angka didalam laporan keuangan sehingga dapat meminimalisasi informasi asimetri.

Penelitian terdahulu mengenai konservatisme terhadap kualitas laba menunjukkan hasil yang tidak konsistenan. Sadidi et al. (2011) menemukan bahwa indeks kualitas laba yang disajikan berdasarkan indeks konservatisme memiliki kemampuan untuk menggambarkan beberapa perbedaan antara return aset operasional dan return saham saat ini dari tahun ini sampai tahun berikutnya sehingga mencerminkan laba yang berkualitas. Penelitian Watts (2003) mengungkapkan akuntansi konservatif bermanfaat untuk menghindari konflik kepentingan antara investor dan kreditor karena konservatisme akuntansi dapat mencegah pembagian dividen yang berlebihan kepada investor. Namun penelitian Penman dan Zhang (2002) memiliki pernyataan berbeda, dimana membuktikan bahwa perusahaan dengan tingkat konservatisme yang tinggi cenderung mengalokasikan cadangannya ke tahun tahun berikutnya sehingga laba cenderung tidak persisten. Ditemukan pula bahwa konservatisme membuat laba dan return menjadi lebih rendah dan menghasilkan unrecorded reserves sehingga membuat kualitas laba yang dilaporkan menjadi lebih rendah. Menurut Givoly dan Hayn (2002), penerapan konsep konservatisme menimbulkan asimetri informasi terkait 
Putu Astri Yunita dan Bambang Suprasto. Pengaruh...

dengan ketepatan waktu, dimana terdapat beberapa kejadian yang tidak langsung diakui saat itu sehingga menimbulkan bias.

Faktor lain yang dianggap mempengaruhi kualitas laba adalah IOS (Investment Opportunity Set). Investasi merupakan komitmen atas sumber daya lainnya yang dilakukan pada saat ini, dengan tujuan memperoleh sejumlah keuntungan dimasa mendatang. Umumnya, IOS mendefinisikan luasnya peluang suatu perusahaan untuk berinvestasi dengan bergantung pada pilihan expenditure perusahaan untuk kepentingan dimasa mendatang. Menurut Adriani (2011), IOS merupakan nilai sekarang dan pilihan perusahaan untuk membuat investasi dimasa mendatang. Investasi dimasa mendatang tidak semata-mata ditunjukkan dengan adanya proyek-proyek yang didukung oleh kegiatan riset dan pengembangan saja, namun juga dengan kemampuan perusahaan dalam mengeksploitasi kesempatan mengambil keuntungan dibandingkan dengan perusahaan lain yang setara dalam suatu kelompok industrinya Gaver dan Gaver (1993), dalam Solechan, (2006).

Banyak penelitian yang menggunakan IOS sebagai variabel independen dengan kualitas laba sebagai fokus penelitiannya, tetapi tidak menunjukkan hasil yang konsisten. Novianti (2010) mengungkapkan bahwa kualitas laba dapat dipengaruhi oleh investment opportunity set karena IOS merupakan kesempatan perusahaan untuk tumbuh dan juga dijadikan sebagai dasar penentu klasifikasi pertumbuhan perusahaan dimasa depan. Selain itu, pada penelitian Warianto (2013) disimpulkan bahwa investment opportunity set (IOS) berpengaruh positif terhadap kualitas laba yang dihitung menggunakan discretionary accruals. Hasil penelitian lain pada penelitian IOS disampaikan oleh Wah (2002) melalui penelitiannya 
mengenai IOS terhadap kualitas laba, dimana menurut Wah perusahaan yang memiliki IOS tinggi memiliki discretionary accruals yang tinggi sehingga menghasilkan laba dengan kualitas yang buruk. Penelitian Smith dan Watts (1992) juga menyatakan manajemen investment opportunities membutuhkan pembuatan keputusan pada lingkungan yang tak pasti sehingga menimbulkan tindakan manajemen yang unobservable yang mengakibatkan prinsipal tidak mengetahui tindakan manajemen, apakah sudah sesuai dengan kepentingan prinsipal atau justru sebaliknya.

Penelitian-penelitian terdahulu yang tidak konsisten serta terdapat fenomena kualitas laba pada beberapa perusahaan manufaktur di Indonesia yang memiliki tingkat fluktuasi yang tinggi membuat peneliti tertarik untuk kembali meneliti dua faktor tersebut yaitu konservatisme dan investment opportunity set pada kualitas laba dengan menambahkan variabel moderasi. Variabel moderasi merupakan variabel yang mempengaruhi (memperkuat dan memperlemah) hubungan antara variabel independen ke dependen (Sugiyono, 2014:59). Variabel moderasi pada penelitian ini yaitu kepemilikan manajerial dimana peneliti berasumsi bahwa dengan adanya kepemilikan manajerial dalam suatu perusahaan dapat mempengaruhi kebijakan-kebijakan yang digunakan untuk mencapai tujuan perusahaan dengan baik sehingga dianggap dapat memperkuat atau memperlemah pengaruh antara konservatisme dan investment opportunity set terhadap kualitas laba yang dihasilkan. 
Putu Astri Yunita dan Bambang Suprasto. Pengaruh...

Kepemilikan manajerial menurut Wahidahwati (2002: 607), merupakan tingkat kepemilikan saham pihak manajemen yang secara aktif ikut dalam pengambilan keputusan, misalnya direktur, manajemen, dan komisaris. Kepemilikan manajerial berarti kondisi dimana manajemen suatu perusahaan ikut menjadi pemegang saham yang aktif dalam mengambil keputusan sekaligus sebagai manajemen perusahaan tersebut. Tarigan, Josua dan Yulius Yogi Christiawan (2007: 2) menyatakan bahwa dalam perusahaan dengan kepemilikan manajerial, manajemen perusahaan menyelaraskan kepentingannya sebagai pemegang saham pada perusahaannya sendiri. Sehingga manajemen lebih berhati-hati dalam mengambil suatu keputusan karena manajemen ikut menanggung hasil keputusan yang telah diambil.

Berdasarkan latar belakang diatas maka didapat rumusan penelitian sebagai berikut: 1) Apakah konservatisme berpengaruh pada kualitas laba? 2) Apakah investment opportunity set berpengaruh pada kualitas laba? 3) Apakah kepemilikan manajerial memengaruhi hubungan antara konservatisme dengan kualitas laba? 4) Apakah kepemilikan manajerial memengaruhi hubungan antarainvestment opportunity set dengan kualitas laba?

Berdasarkan rumusan masalah yang telah diuraikan, maka tujuan dari penelitian ini adalah sebagai berikut: 1) Untuk mengetahui dan memberikan bukti empiris pengaruh konservatisme pada kualitas laba; 2) Untuk mengetahui dan memberikan bukti empiris pengaruh investment opportunity set pada kualitas laba; 3) Untuk mengetahui dan memberikan bukti empiris kepemilikan manajerial mempengaruhi hubungan antara konservatisme pada kualitas laba; 4) Untuk 
mengetahui dan memberikan buki empiris kepemilikan manajerial mempengaruhi hubungan antara investment opportunity set pada kualitas laba.

Kegunaan penelitian yang diharapkan adalah sebagai berikut: 1) Kegunaan Teoritis, penelitian ini diharapkan mampu memperluas wawasan dan pemahaman terhadap kualitas laba dan memberi kontribusi berdasarkan goal-setting theory dan teori sinyal serta faktor-faktor yang mempengaruhinya baik buruknya kualitas laba pada suatu perusahaan. 2) Kegunaan Praktis, penelitian ini diharapkan dapat menjadi pedoman bagi investor dan calon investor dalam mengambil keputusan investasi, menentukan kualitas laba bagi perusahaan serta sebagai masukan dan refrensi bagi peneliti selanjutnya.

Watts (2003) menyatakan bahwa konservatisme berubah menjadi faktor kehati-hatian dalam laporan keuangan setelah sebelumnya merupakan faktor elemen kualitatif laporan keuangan. Adapun pengertian kehati-hatian tersebut yaitu tidak melaporkan aset secara overvalue dan tidak melaporan kewajiban secara undervalue pada saat akuntan menghadapi ketidakpastian untuk menilai aset dan liabilitas. Penelitian yang memfokuskan kepada kualitas laba dengan indeks konservatisme akuntansi telah dilakukan oleh beberapa peneliti. Penelitian tersebut diantaranya yang dilakukan oleh Watts (2003), dimana pada penelitian tersebut mengungkapkan akuntansi konservatif bermanfaat untuk menghindari konflik kepentingan antara investor dan kreditor karena konservatisme akuntansi dapat mencegah pembagian dividen yang berlebihan kepada investor. Selaras dengan hasil penelitian Watts, Sadidi (2011) juga mengungkapkan konservatisme akuntansi berpengaruh terhadap kualitas laba, dimana penelitian tersebut 
Putu Astri Yunita dan Bambang Suprasto. Pengaruh...

mengungkapkan bahwa indeks kualitas laba yang disajikan berdasarkan indeks konservatisme memiliki kemampuan untuk menggambarkan perbedaan return aset operasional dan return saham saat ini sampai dengan tahun berikutnya sehingga mencerminkan laba yang berkualitas. Fala (2007) menemukan bahwa terdapat hubungan positif signifikan antara konservatisme akuntansi terhadap penilaian ekuitas perusahaan sehingga konservatisme akuntansi yang tinggi mencerminkan nilai perusahaan yang tinggi pula. Berdasarkan hasil penelitian-penelitian terdahulu, dapat diasumsikan bahwa konservatisme akuntansi yang memiliki konsep kehati-hatian dalam menghadapi resiko bisnis yang kemungkinan terjadi menghasilkan informasi laba yang berkualitas sehingga memudahkan para investor dapat mengambil keputusan yang tepat. Berdasarkan teori dan hasil penelitian sebelumnya, maka hipotesis yang diajukan dalam penelitian ini adalah sebagai berikut:

$\mathrm{H}_{1}$ : Konservatisme berpengaruh positif terhadap kualitas laba.

Hartono (1999) dalam Adriani (2011) menyatakan bahwa investment opportunity set (IOS) adalah tersedianya alternatif investasi dimasa mendatang bagi perusahaan. IOS merupakan nilai sekarang dan pilihan perusahaan untuk membuat investasi dimasa mendatang. Investment opportunity set (IOS) dapat mempengaruhi kualitas laba karena IOS merupakan kesempatan perusahaan untuk tumbuh dan juga dijadikan sebagai dasar penentu klasifikasi pertumbuhan perusahaan di masa depan (Novianti, 2010). Selain itu, penelitian Suaryana (2005) menyatakan adanya peluang atau kesempatan untuk tumbuh yang dihadapi perusahaan di waktu medatang merupakan suatu prospek baik yang dapat mendatangkan laba bagi 
perusahaan. Investment opportunity set berpengaruh positif terhadap kualitas laba yang dihitung dengan menggunakan discretionary accruals (Warianto, 2013). Oleh karena itu, peneliti berasumsi bahwa adanya IOS atau kesempatan bertumbuh yang tinggi pada suatu perusahaan dapat meningkatkan pertumbuhan laba dimasa mendatang. Peningkatan laba yang stabil dari suatu perusahaan menunjukkan bahwa pertumbuhan laba perusahaan baik. Jika semakin besar kesempatan bertumbuh perusahaan maka semakin tinggi kesempatan perusahaan menambah laba yang diperoleh dimasa mendatang, sehingga kualitas laba yang dihasilkan juga meningkat dan dapat digunakan untuk memprediksi laba dimasa mendatang. Berdasarkan teori dan hasil penelitian sebelumnya, maka hipotesis yang diajukan dalam penelitian ini adalah sebagai berikut:

$\mathrm{H}_{2}$ : Investment opportunity set berpengaruh positif terhadap kualitas laba.

Proksi kepemilikan manajerial dimasukkan sebagai pemoderasi pada penelitian ini. Kepemilikan manajerial merupakan jumlah kepemilikan saham oleh pihak manajemen dari seluruh modal saham perusahaan yang dikelola (Boediono, 2005). Penelitian yang dilakukan oleh Gabrielsen et al. (2002), Yeo et al. (2002) dan Midiastuty et al. (2003) memeberikan kesimpulan bahwa adanya kepemilikan manajerial dalam suatu perusahaan akan memberikan pengaruh terhadap kualitas laba yang akan dihasilkan. Selain itu, peneliti juga berasumsi bahwa dengan manajer merangkap sebagai pemegang saham pada suatu perusahaan dianggap akan menuntut manajer lebih berhati-hati dalam menyajikan laporan keuangan yang selaras dengan konsep konservatisme akuntansi sehingga dapat meminimalisasi risiko-risiko bisnis yang kemungkinan akan terjadi dan akan mempengaruhi 
Putu Astri Yunita dan Bambang Suprasto. Pengaruh...

kualitas laba yang dihasilkan pada laporan keuangan untuk nantinya digunakan sebagai alat untuk pengambilan keputusan bagi para pemegang saham perusahaan. Berdasarkan teori dan hasil penelitian sebelumnya, maka hipotesis yang diajukan dalam penelitian ini adalah sebagai berikut:

$\mathrm{H}_{3}$ : Kepemilikan manajerial memperkuat pengaruh konservatisme akuntansi terhadap kualitas laba.

Investment opportunity set (IOS) dapat didefinisikan sebagai kesempatan atau peluang untuk perusahaan dalam berinvestasi di masa mendatang. IOS merupakan nilai sekarang dan pilihan perusahaan untuk membuat investasi dimasa mendatang (Myers 1977, dalam Adriani, 2011). IOS yang tinggi pada suatu perusahaan memiliki dampak pada pertumbuhan perusahaan yang semakin baik dimasa mendatang. Pertumbuhan perusahaan yang baik juga dapat dipengaruhi oleh adanya kepemilikan manajerial, karena manajer yang sekaligus menjadi pemegang saham memaksimalkan kinerja perusahaannya sehingga nantinya perusahaan memiliki prospek pertumbuhan yang baik. Penelitian yang dilakukan oleh Morck et al. (1989) menyatakan kepentingan manajer dan pemegang saham dapat diselaraskan bila manajer memiliki saham perusahaan yang lebih besar. Dengan demikian, peneliti berasumsi bahwa tingginya tingkat kepemilikan manajerial pada suatu perusahaan yang disertai dengan adanya IOS pada suatu perusahaan menyebabkan suatu perusahaan mempunyai prospek pertumbuhan yang baik dimasa mendatang sehingga menghasilkan laba yang berkualitas. Berdasarkan teori dan hasil penelitian sebelumnya, maka hipotesis yang diajukan dalam penelitian ini adalah sebagai berikut: 
$\mathrm{H}_{4}$ : Kepemilikan manajerial memperkuat pengaruh investment opportunity set terhadap kualitas laba.

\section{METODE PENELITIAN}

Penelitian ini dilakukan pada Bursa Efek Indonesia (BEI) dengan mengakses website www.idx.co.id untuk mengunduh laporan keuangan dan annual report perusahaan-perusahaan manufakturyang menjadi sampel sebagai data dari tahun 2013-2015. Objek penelitian ini adalah perusahaan-perusahaan yang mengeluarkan laporan keuangan dan annual report secara berturut-turut serta memenuhi data lain yang diperlukan dalam variabel penelitian ini. Penelitian ini mengidentifikasi 3 variabel, yaitu: 1) variabel independen yakni konservatisme akuntansi dan investment opportunity set; 2) variabel dependen yaitu kualitas laba; 3) Variabel moderasi yakni kepemilikan manajerial.

Jenis data yang digunakan dalam penelitian ini adalah data kuantitatif yaitu data laporan tahunan dan annual report perusahaan periode tahun 2013-2015. Data yang digunakan merupakan data yang dapat diperoleh melalui website www.idx.co.id. Data penelitian ini menggunakan data sekunder meliputi data perusahaan manufaktur periode 2013-2015 yang dipandang cukup mewakili kondisi-kondisi perusahaan di Indonesia. Alasan menggunakan data dari Bursa Efek Indonesia dan yahoo finance adalah karena mempresentasikan kondisi bisnis dan pasar modal yang terjadi di Indonesia.

Populasi pada penelitian ini yaitu seluruh perusahaan manufaktur yang terdaftar di BEI tahun 2013-2015. Sampel yang digunakan dalam penelitian ini adalah perusahaan manufaktur yang terdaftar di Bursa Efek Indonesia (BEI) dimana 
pengambilan sampel dalam penelitian ini dilakukan dengan menggunakan metode purposive sampling. Adapun kriterianya dalam penentuan sampel penelitian ini sebagai berikut:1) Perusahaan sampel tidak mengalami delisting selama periode pengamatan; 2) Perusahaan yang mempublikasikan annual report dan laporan keuangan secara lengkap dari tahun 2013 sampai dengan 2015; 3) Perusahaan menggunakan mata uang rupiah dalam laporan keuangan perusahaan selama periode pengamatan tahun 2013-2015; 4) Menyajikan data yang berkaitan dengan variabel penelitian.

Metode pengumpulan data yang digunakan dalam penelitian ini adalah dengan melakukan studi dokumentasi yang dilakukan dengan mengumpulkan data sekunder dari situs BEI yaitu www.idx.co.id. Data sekunder yang dimaksud adalah laporan keuangan dan annual report perusahaan manufaktur priode 2013-2015 sesuai dengan kriteria pemilihan sampel. Beberapa pengujian data yang dilaksanakan dalam penelitian ini ialah uji asumsi klasik terdiri dari uji normalitas, uji heteroskedastisitas, dan uji autokorelasi, setelah itu dilaksanakan uji Moderating Regression Analysis (MRA).

\section{HASIL DAN PEMBAHASAN}

Penelitian ini menggunakan perusahaan manufaktur yang terdaftar di Bursa Efek Indonesia (BEI) periode tahun 2013-2015. Perusahaan manufaktur yang dijadikan sampel berjumlah 63 perusahaan dengan waktu pengamatan selama 3 tahun yang berarti jumlah data penelitian ini sebanyak 63 perusahaan $\times 3$ tahun $=189$ data amatan. Pengambilan sampel dalam penelitian ini menggunakan metode non probability dengan teknik purposive sampling yaitu dengan menggunakan kriteria 
tertentu untuk pemilihan sampel. Kriteria pemilihan sampel penelitian ini disajikan dalam Tabel 2 sebagai berikut.

Tabel 2. Penentuan Jumlah Sampel

\begin{tabular}{|c|c|c|}
\hline No. & $\begin{array}{c}\text { Kriteria Sampel } \\
\end{array}$ & Jumlah \\
\hline 1 & $\begin{array}{l}\text { Perusahaan manufaktur yang terdaftar di Bursa Efek } \\
\text { Indonesia dari tahun 2013-2015 }\end{array}$ & 144 \\
\hline 2 & $\begin{array}{l}\text { Perusahaan yang mengalami delisting selama periode } \\
\text { 2013-2015 }\end{array}$ & (4) \\
\hline 3 & $\begin{array}{l}\text { Perusahaan yang tidak menerbitkan annual report dan } \\
\text { laporan keuangan secara lengkap dari tahun 2013-2015 }\end{array}$ & $(20)$ \\
\hline 4 & $\begin{array}{l}\text { Perusahaan yang tidak menggunakan mata uang rupiah } \\
\text { dalam laporan keuangan perusahaan selama periode } \\
\text { tahun 2013-2015 }\end{array}$ & $(26)$ \\
\hline 5 & Dikeluarkan karena data tidak lengkap & $(7)$ \\
\hline 6 & Data outlier & (24) \\
\hline \multicolumn{2}{|c|}{ Jumlah sampel } & 63 \\
\hline \multicolumn{2}{|c|}{ Jumlah pengamatan penelitian (3 tahun) } & 189 \\
\hline
\end{tabular}

Berdasarkan Tabel 2 menunjukkan bahwa data di-outlier sebanyak 24. Hal tersebut dilaksanakan karena nilai lebih besar dari 2.5 dan lebih kecil dari 2.5 dari standar deviasi maka data tersebut harus dihilangkan untuk menghindari hasil penelitian yang bias. Statistik deskriptif disajikan untuk memberikan informasi mengenai karakteristik variabel-variabel penelitian, seperti nilai minimum, nilai maksimum, nilai rata-rata dan deviasi standar. Nilai rata-rata (mean) merupakan langkah yang paling aman yang digunakan untuk mengukur nilai sentral dari suatu distribusi data. Standar deviasi menunjukkan seberapa luas atau rentangan antara nilai minimum dengan nilai maksimum dari masing-masing variabel. Statistik deskriptif dari variabel-variabel yang digunakan dalam penelitian ini ditunjukkan pada Tabel 3 berikut:

Tabel 3. Hasil Statistik Deskriptif

\begin{tabular}{lrllrl}
\hline & N & Minimum & \multicolumn{1}{c}{ Maksimum } & Mean & Std. Deviation \\
\hline KV & 189 & $-2,6952$ & 10,2074 & 1,446368 & 1,5208605 \\
IOS & 189 & 0,3326 & 4,2535 & 1,277768 & 0,7838559 \\
\hline
\end{tabular}


Putu Astri Yunita dan Bambang Suprasto. Pengaruh...

\begin{tabular}{|c|c|c|c|c|c|c|}
\hline KM & & 189 & 0,1051 & 0,9796 & 0,537440 & 0,2345544 \\
\hline KV_KM & & 189 & $-2,3057$ & 4,4974 & 0,821731 & 0,9491732 \\
\hline IOS_KM & & 189 & 0,0806 & 2,8268 & 0,705302 & 0,5496295 \\
\hline DA & & 189 & $-0,1875$ & 0,2241 & 0,005825 & 0,0753520 \\
\hline $\begin{array}{l}\text { Valid } \\
\text { (listwise) }\end{array}$ & $\mathbf{N}$ & 189 & & & & \\
\hline
\end{tabular}

Berdasarkan hasil analisis pada Tabel 3 maka deskripsi statistik diatas adalah sebagai berikut: Variabel KV yang menggambarkan konservatisme dengan jumlah 189 sampel memiliki nilai minimum sebesar -2,6952 pada PT. RIMBA tahun 2014 dan nilai maksimum sebesar 10,2074 pada PT. NIPS tahun 2013. Variabel konservatisme memiliki nilai rata-rata (mean) sebesar 1,446368 menyebabkan kurva distibusi condong ke kiri dimana nilai tersebut mendekati nilai minimum dari variabel konservatisme yang artinya tingkat penerapan konservatisme pada perusahaan manufaktur yang menjadi sampel penelitian ini masih rendah. Nilai standar deviasi sebesar 1.5208605 menunjukkan bahwa sebaran data variabel konservatisme pada perusahaan sampel mendekati nilai minimum dan cenderung variatif karena memiliki rentang jarak minimum dan maksimum yang cukup jauh.

Variabel IOS yang menggambarkan Investment Opportunity Set memiliki nilai minimum sebesar 0,3326 pada PT. JPRS tahun 2015 dan nilai maksimum sebesar 4,2535 pada PT. SMSM tahun 2014. Variabel IOS memiliki nilai rata-rata (mean) sebesar 1,277768 menyebabkan kurva distribusi condong ke kiri dimana nilai tersebut mendekati nilai minimum dari variabel IOS yang artinya tingkat IOS pada perusahaan manufaktur yang menjadi sampel penelitian ini masih rendah. Nilai standar deviasi sebesar 0.7838559 menunjukkan bahwa sebaran data untuk 
variabel investment opportunity set pada perusahaan sampel mendekati nilai minimum dan tidak begitu variatif karena memiliki rentang jarak minimum dan maksimum yang cukup dekat.

Variabel KM yang menggambarkan kepemilikan manajerial memiliki nilai minimum sebesar 0,1051 pada PT. MYRX tahun 2013 dan nilai maksimum sebesar 0,9796 pada PT. SOBI tahun 2013, 2014, dan 2015. Variabel kepemilikan manajerial memiliki nilai rata-rata (mean) sebesar 0,537440 menyebabkan kurva berdistribusi normal dimana nilai tersebut memiliki arti tingkat kepemilikan manajerial pada perusahaan manufaktur yang menjadi sampel penelitian ini normal. Nilai standar deviasi sebesar 0.2345544 menunjukkan bahwa sebaran data untuk variabel kepemilikan manajerial pada perusahaan sampel mendekati nilai minimum dan cenderung variatif karena memiliki rentang jarak minimum dan maksimum yang cukup jauh.

Variabel DA yang menggambarkan kualitas laba memiliki nilai minimum sebesar -0,1875 pada PT. SIPD tahun 2015 dan nilai maksimum sebesar 0,2241 pada PT. NIPS tahun 2013. Variabel kualitas laba memiliki nilai rata-rata (mean) sebesar 0,005825 menyebabkan kurva distribusi condong ke kiri dimana nilai tersebut mendekati nilai minimum dari variabel kualitas laba yang artinya tingkat kualitas laba pada perusahaan manufaktur yang menjadi sampel penelitian ini masih rendah. Nilai standar deviasi sebesar 0.0753520 menunjukkan bahwa sebaran data untuk variabel kualitas laba pada perusahaan sampel mendekati nilai minimum dan tidak begitu variatif karena memiliki rentang jarak minimum dan maksimum yang cukup dekat. 
Uji asumsi klasik dilakukan pada data yang digunakan untuk penelitian ini dengan tujuan menghasilkan model regresi bersifat BLUE (Best Linier Unbiased Estimator). Uji asumsi klasik yang dilaksanakan dalam penelitian ini terdiri dari uji normalitas, heteroskedastisitas, dan autokorelasi.

Ghozali (2012) menyebutkan uji normalitas bertujuan untuk menguji apakah dalam residual dari model regresi yang dibuat berdistribusi normal atau tidak. Hasil dari uji normalitas disajikan dalam Tabel 4 berikut ini.

Tabel 4. Hasil Uji Normalitas

\begin{tabular}{lc}
\hline Kolmogorov-Smirnov & Unstandardized Residual \\
\hline $\mathbf{N}$ & 189 \\
Asymp.Sig.(2-tailed) & 0,200 \\
\hline er: Hasil Output SPSS, 2017 &
\end{tabular}

Tabel 4 menunjukkan bahwa nilai signifikansi sebesar 0,200 >0.05. Hal ini berarti model regresi dalam penelitian ini berdistribusi normal.

Uji autokorelasi bertujuan untuk menguji ada tidaknya korelasi antara variabel pada periode tertentu dengan variabel periode sebelumnya. Model regresi yang baik seharusnya tidak terjadi autokorelasi. Pengukuran data yang terkena autokorelasi atau tidak, dapat dilihat dari nilai Durbin-Watson (DW-test), dengan ketentuan jika du $<$ DW $<(4-d u)$ maka tidak terdapat autokorelasi. Hasil uji autokorelasi dapat dilihat pada Tabel 5 berikut ini:

Tabel 5. Hasil Uji Autokorelasi

\begin{tabular}{cc}
\hline Model & Durbin- Watson \\
\hline 1 & 2,110 \\
\hline Sumber: Hasil Output SPSS, 2017 &
\end{tabular}


Berdasarkan Tabel 5 diperoleh nilai DW sebesar 2,110. Nilai dU untuk jumlah sampel 189 dengan 5 variabel bebas $(\mathrm{k})$ serta $\alpha=5 \%$ adalah 1.72. Maka nilai $4-\mathrm{dU}$ adalah 2.18, sehingga hasil uji autokorelasinya adalah $\mathrm{dU}<\mathrm{DW}<4-\mathrm{dU}$ yaitu $1.72<2,110<2.18$, maka data bebas autokorelasi.

Uji heteroskedastisitas bertujuan untuk menguji apakah dalam model regresi terjadi ketidaksamaan variance dari residual satu pengamatan ke pengamatan lainnya (Ghozali, 2013:139). Hasil uji heteroskedastisitas dapat dilihat pada Tabel6 berikut.

Tabel 6. Hasil Uji Heteroskedastisitas

\begin{tabular}{cc}
\hline Variabel & Signifikansi \\
\hline $\mathbf{K V}\left(\mathbf{X}_{\mathbf{1}}\right)$ & 0,106 \\
$\mathbf{I O S}\left(\mathbf{X}_{\mathbf{2}}\right)$ & 0,133 \\
$\mathbf{K M}\left(\mathbf{X}_{2}\right)$ & 0,086 \\
\hline
\end{tabular}

Sumber: Hasil Output SPSS, 2017

Berdasarkan Tabel6 dapat dilihat nilai signifikansi setiap variabel bebas bernilai lebih besar dari $\alpha(0.05)$. Hasil ini menunjukan bahwa data bebas dari gejala heterokedastisitas.

Uji kelayakan model (uji F) merupakan tahapan awal mengidentifikasi model regresi yang diestimasi layak atau tidak. Sedangkan, koefisien determinasi mengukur seberapa jauh kemampuan model dalam menjelaskan variansi variabel dependen. Hasil uji kelayakan model dan uji determinasi ditunjukkan pada Tabel 7 berikut.

Tabel 7. Hasil Uji Kelayakan Model dan Uji Determinasi

\begin{tabular}{llll}
\hline Model & F & Sig. & Adjusted R Square \\
\hline Regression & 2,718 & 0,021 & 0,044 \\
\hline Sumber: Hasil Output SPSS, 2017 & &
\end{tabular}


Putu Astri Yunita dan Bambang Suprasto. Pengaruh...

Berdasarkan Tabel 7, nilai $p$-value dari uji F sebesar $0,021<0.05$. Hal ini menunjukkan bahwa model regresi penelitian ini fit atau mampu menjelaskan pengaruh variabel independen terhadap variabel dependen. Nilai dari adjusted $R$ squarepada Tabel 7 menunjukkan 0,044 atau 4,4\%, ini artinya sebesar 4,4\% variasi kualitas laba dipengaruhi oleh variabel konservatisme dan Investment Opportunity Set, sedangkan sisanya sebesar $95,6 \%$ dijelaskan oleh faktor lain yang tidak dijelaskan dalam model penelitian ini.

Uji hipotesis (Uji t) digunakan untuk menguji signifikansi masing-masing variabel secara parsial. Hasil uji t dapat dilihat pada Tabel 8 berikut.

\begin{tabular}{|c|c|c|c|c|c|c|}
\hline & \multirow{2}{*}{ Model } & \multicolumn{2}{|c|}{$\begin{array}{l}\text { Unstandardized } \\
\text { Coefficients }\end{array}$} & \multirow{2}{*}{$\begin{array}{c}\begin{array}{c}\text { Standardized } \\
\text { Coefficients }\end{array} \\
\text { Beta }\end{array}$} & \multirow{2}{*}{$\mathbf{T}$} & \multirow{2}{*}{ Sig. } \\
\hline & & B & Std. Error & & & \\
\hline \multirow[t]{6}{*}{1} & (Constant) & 0,019 & 0,029 & & 0,655 & 0,513 \\
\hline & KV & 0,042 & 0,017 & 0,843 & 2,441 & 0,016 \\
\hline & IOS & $-0,055$ & 0,033 & $-0,577$ & $-1,675$ & 0,096 \\
\hline & KM & $-0,017$ & 0,052 & $-0,054$ & $-0,334$ & 0,739 \\
\hline & KV_KM & $-0,038$ & 0,029 & $-0,476$ & $-1,315$ & 0,190 \\
\hline & IOS_KM & 0,053 & 0,056 & 0,386 & 0,948 & 0,344 \\
\hline
\end{tabular}

Sumber: Hasil Output SPSS, 2017

Berdasarkan Tabel 8 hasil uji t memiliki arti sebagai berikut: Hipotesis pertama $\left(\mathrm{H}_{1}\right)$ penelitian ini menyatakan bahwa konservatsime berpengaruh positif terhadap kualitas laba. Berdasarkan hasil uji pada Tabel 8 di atas dapat dilihat bahwa nilai $p$-value untuk variabel konservatisme adalah 0,016 dengan nilai koefisien regresi sebesar 0,042. Hasil uji statistik tersebut menunjukkan konservatisme berpengaruh positif terhadap kualitas laba, sehingga $\mathrm{H}_{1}$ diterima.

Hipotesis kedua $\left(\mathrm{H}_{2}\right)$ penelitian ini menyatakan bahwa investment opportunity set berpengaruh positif terhadap kualitas laba. Berdasarkan hasil uji 
pada Tabel 8 dapat dilihat nilai p-value untuk variabel investment opportunity set sebesar 0,096 dengan nilai koefisien regresi sebesar -0,055. Hasil uji statistik tersebut menunjukkan investment opportunity set tidak berpengaruh terhadap kualitas laba, sehingga $\mathrm{H}_{2}$ ditolak.

Hipotesis ketiga $\left(\mathrm{H}_{3}\right)$ penelitian ini menyatakan bahwa kepemilikan manajerial memoderasi pengaruh konservatisme terhadap kualitas laba. Berdasarkan hasil uji pada Tabel 8 diatas dapat dilihat interaksi kepemilikan manajerial dengan konservatisme memiliki nilai $p$-value sebesar 0,190 dengan nilai koefisien regresi sebesar -0,038. Hasil uji statistik tersebut menunjukkan kepemilikan manajerial tidak mampu memoderasi pengaruh konservatisme terhadap kualitas laba, sehingga $\mathrm{H}_{3}$ ditolak.

Hipotesis keempat $\left(\mathrm{H}_{4}\right)$ penelitian ini menyatakan bahwa kepemilikan manajerial memoderasi pengaruh investment opportunity set terhadap kualitas laba. Berdasarkan hasil uji pada Tabel 8 dapat dilihat interaksi kepemilikan manajerial dengan investment opportunity set memiliki nilai p-value sebesar 0,344 dengan nilai koefisien regresi sebesar 0,053. Hasil uji statitik tersebut menunjukkan kepemilikan manajerial tidak mampu memoderasi pengaruh investment opportunity set terhadap kualitas laba, sehingga $\mathrm{H}_{4}$ ditolak.

Hipotesis pertama $\left(\mathrm{H}_{1}\right)$ penelitian ini menyatakan bahwa konservatisme berpengaruh positif terhadap kualitas laba. Sesuai dengan hasil uji hipotesis t yang telah dijelaskan sebelumnya, terdapat pengaruh yang signifikan antara konservatisme dan kualitas laba. Koefisien penelitian yang berarah positif menunjukan hubungan positif antara konservatisme dengan kualitas laba. 
Putu Astri Yunita dan Bambang Suprasto. Pengaruh...

Meningkatnya nilai konservatisme dapat meningkatkan kualitas laba. Hasil penelitian ini mendukung goal-setting theory dimana teori tersebut memiliki asumsi bahwa seseorang yang mampu memahami tujuan yang diharapkan oleh organisasi, maka pemahaman tersebut mampu mempengaruhi perilaku kerjanya. Pemahaman manajer terhadap tujuan perusahaan untuk menyajikan laba yang berkualitas dapat menerapkan prinsip-prinsip yang menghasilkan kualitas laba yang baik dengan salah satunya menerapkan prinsip konservatisme. Laba yang disajikan berdasarkan prinsip konservatisme merupakan laba yang tidak bias nilainya sehingga dapat dianggap sebagai laba yang berkualitas.

Hasil penelitian ini sesuai dengan penelitian Watts (2003), Fala (2007), dan Sadidi (2011) yang menyatakan konservatisme akuntansi berpengaruh positif terhadap kualitas laba. Indeks kualitas laba yang disajikan berdasarkan indeks konservatisme memiliki kemampuan untuk menggambarkan perbedaan return aset operasional dan return saham saat ini sampai dengan tahun berikutnya. Akuntansi konservatif juga bermanfaat untuk menghindari konflik kepentingan antara investor dan kreditor karena konservatisme akuntansi dapat mencegah pembagian dividen yang berlebihan kepada investor. Berdasarkan penjelasan goal-setting theory serta penelitian-penelitian terdahulu maka dapat disimpulkan bahwa konservatisme berpengaruh positif terhadap kualitas laba, sehingga $\mathrm{H}_{1}$ diterima.

Hipotesis kedua $\left(\mathrm{H}_{2}\right)$ penelitian ini menyatakan bahwa investment opportunity set berpengaruh positif terhadap kualitas laba. Sesuai dengan hasil uji hipotesis $\mathrm{t}$ yang telah dijelaskan sebelumnya, peneliti tidak dapat membuktikan hipotesis kedua $\left(\mathrm{H}_{2}\right)$ tersebut. Hasil penelitian ini tidak mampu mendukung teori 
sinyal. Teori sinyal didasarkan pada asumsi pemberian sinyal yang dilakukan oleh manajemen perusahaan untuk menghindari adanya asimetri informasi. Pemberian sinyal yang dimaksud adalah pengungkapan informasi akuntansi berupa laporan keuangan kepada para stakeholder. Pertumbuhan perusahaan yang tinggi cenderung melakukan perataan laba dan manipulasi laba sehingga kualitas laba yang dihasilkan menjadi rendah dimana mengakibatkan informasi yang diterima oleh para penggunanya tidak sesuai dengan keadaan sebenarnya.

Hasil penelitian ini sesuai dengan penelitian Wah (2002), Shen dan Chih (2007), dan Kartina dan Nikamh (2011) yang menyatakan investment opportunity set tidak berpengaruh terhadap kualitas laba. Perusahaan yang memiliki tingkat investment opportunity set tinggi memiliki discretionary accruals (akrual kelolaan) sebagai proksi dari kualitas laba yang tinggi. Pasar juga tidak menganggap bahwa pengeluaran investasi sebagai hal yang dipertimbangkan dalam menentukan kualitas laba yang diumumkan oleh pasar. Berdasarkan penjelasan teori sinyal dan penelitian-penelitian terdahulu maka dapat disimpulkan bahwa investment opportunity set berpengaruh negatif kualitas laba, sehingga $\mathrm{H}_{2}$ ditolak.

Hipotesis ketiga $\left(\mathrm{H}_{3}\right)$ penelitian ini menyatakan kepemilikan manajerial memperkuat pengaruh konservatisme terhadap kualitas laba. Berdasarkan hasil uji hipotesis t yang telah dijelaskan sebelumnya, peneliti tidak dapat membuktikan hipotesis ketiga $\left(\mathrm{H}_{3}\right)$ tersebut. Hasil penelitian ini tidak mampu mendukung konsep dari goal-setting theory yang didasarkan pada asumsi adanya pemahaman terhadap tujuan yang telah ditetapkan dalam suatu organisasi dengan perilaku yang dihasilkan memiliki hubungan yang sangat penting untuk perusahaan itu sendiri. 
Putu Astri Yunita dan Bambang Suprasto. Pengaruh...

Tingginya tingkat kepemilikan manajerial di suatu perusahaan cenderung dapat memanipulasi laba dengan tujuan untuk meningkatkan kepemilikan manajerial tersebut sehingga menurunkan kualitas laba. Hal ini tidak sesuai dengan tujuan perusahaan yaitu menghasilkan laba yang berkualitas sesuai dengan keadaan yang sebenarnya pada perusahaan tersebut.

Hasil penelitian ini sesuai dengan penelitian yang dilakukan oleh Magdalena (2008) dan Razak (2012) yang menyatakan bahwa kepemilikan manajerial tidak mampu memoderasi hubungan antara konservatisme terhadap kualitas laba. Pada suatu perusahaan, persentase kepemilikan manajerial yang tinggi dapat menimbulkan tindakan menaikan laba untuk kepentingan pribadi sehingga merugikan pihak stakeholder perusahaan tersebut. Hal ini tidak sejalan dengan konsep konservatisme yakni menunda pengakuan pendapatan dan keuntungan yang diperoleh serta mengakui biaya dan rugi lebih awal dengan tujuan untuk meminimalisir adanya tindakan menaikan laba yang dilakukan oleh manajemen perusahaan. Berdasarkan penjelasan dari goal-setting theory serta penelitian terdahulu maka dapat disimpulkan bahwa kepemilikan manajerial tidak dapat memoderasi pengaruh konservatisme terhadap kualitas laba, sehingga $\mathrm{H}_{3}$ ditolak.

Hipotesis keempat $\left(\mathrm{H}_{4}\right)$ penelitian ini menyatakan kepemilikan manajerial memperkuat pengaruh investment opportunity set terhadap kualitas laba. Berdasarkan hasil uji hipotesis t yang telah dijelaskam sebelumnya, peneliti tidak dapat membuktikan hipotesis keempat $\left(\mathrm{H}_{4}\right)$ tersebut. Hasil penelitian ini tidak mampu mendukung goal-setting theory. Goal-setting theory memiliki asumsi 
bahwa seseorang yang mampu memahami tujuan yang diharapkan oleh organisasi, maka pemahaman tersebut mempengaruhi perilaku kerjanya. Manajer yang paham terhadap tujuan perusahaannya memiliki perilaku kerja yang fokus terhadap tujuan tersebut. Namun, ketika suatu perusahaan memiliki tingkat kepemilikan manajemen yang cukup tinggi maka kepentingan manajer terhadap perusahaan menjadi lebih dekat dengan kepentingan pemilik. Perusahaan yang dikelola oleh manajer dengan memiliki tingkat persentase saham perusahaan dapat mempengaruhi tindakan manajemen laba sehingga berdampak pada kualitas laba yang dihasilkan.

Hasil penelitian ini sesuai dengan penelitian La Porta et, al (2002), Siallagan dan Machfoedz (2006) yang menyatakan bahwa kepemilikan manajerial tidak mampu memoderasi hubungan antara investment opportunity set terhadap kualitas laba. Suatu perusahaan yang memiliki tingkat kepemilikan manajerial yang tinggi cenderung menimbulkan adanya praktik manipulasi laba untuk kepentingan pribadi yang merugikan pihak stakeholder. Sehingga meskipun perusahaan memiliki tingkat investment opportunity set yang tinggi, para investor ragu untuk menanamkan modalnya dimasa mendatang karena laba yang dihasilkan tidak berkualitas akibat dari sikap opportunistic pihak manajemen perusahaan. Berdasarkan penjelasan teori agensi dan penelitian-penelitian terdahulu maka dapat disimpulkan bahwa kepemilikan manajerial tidak mampu memoderasi pengaruh investment opportunity set terhadap kualitas laba, sehingga $\mathrm{H}_{4}$ ditolak. 
Putu Astri Yunita dan Bambang Suprasto. Pengaruh...

\section{SIMPULAN}

Berdasarkan hasil uji statistik yang telah dilakukan, dari 4 pengujian satu hipotesis diterima sedangkan tiga hipotesis ditolak. Satu hipotesis yang diterima yaitu hipotesis pertama yang membuktikan bahwa konservatisme berpengaruh positif terhadap kualitas laba dimana tingkat konservatisme yang tinggi akan meningkatkan kualitas laba, sedangkan hipotesis kedua yaitu investment opportunity set berpengaruh negatif terhadap kualitas laba.Tingginya tingkat investment opportunity set dapat menurunkan kualitas laba di suatu perusahaan.Penelitian ini juga tidak dapat membutikan kepemilikan manajerial mampu memoderasi konservatisme dan investment opportunity set terhadap kualitas laba. Indeks kualitas laba yang disajikan berdasarkan indeks konservatisme memiliki kemampuan untuk menggambarkan perbedaan return aset operasional dan return saham saat ini sampai dengan tahun berikutnya, selain itu penerapan konservatisme dapat meminimalisir tindakan opportunistic pihak manajemen perusahaan untuk menaikan laba sehingga laba yang disajikan menjadi berkualitas.

Kualitas laba merupakan kemampuan laba pada saat menyajikan laba sebenarnya pada perusahaan dan membantu memprediksi laba dimasa mendatang. Berdasarkan hasil penelitian, untuk meningkatkan kualitas laba sebaiknya perusahaan: 1) Menerapkan konsep konservatisme atau tidak melaporkan aset secara overvalue dan pendapatan secara undervalue pada saat menyajikan laporan keuangan agar laba yang dihasilkan berkualitasserta mengurangi tindakan-tindakan opportunistic dari pihak manajemen untuk menghindari terjadinya bias dalam laporan keuangan sehingga kualitas laba tetap terjaga. 2) Bagi calon investor, agar 
lebih mempertimbangkan kembali saat menanamkan modalnya pada suatu perusahaan mengenai faktor-faktor yang berkaitan dengan kualitas laba karena meskipun laba terlihat tinggi namun tidak menutup kemungkinan adanya tindakan manipulasi laba dari pihak manajemen perusahaan sehingga nantinya para investor tidak salah dalam mengambil keputusan khususnya dalam berinvestasi.

\section{REFERENSI}

Anton Wahyu Utomo dan Luciana Spica Almilia, 2006. Faktor-faktor Yang mempengaruhi Tingkat Suku Bunga Deposito Berjangka Pada Bank Umum di Indonesia. Surabaya: Jurnal Ekonomi dan Bisnis Antisipasi, STIE Perbanas Surabaya.

Bandi. 2009. Kualitas Laba Dalam Perspektif Akrual-Arus Kas dan Pensinyalan Dividen. Disertasi. Universitas Diponegoro Semarang

Basu, Sidupta. 2009. Conservatism Research: Historical Development and Future Prospect. China Journal of Accounting Research, 2(1).

Bellovary, JL., Giacomino, Don E., and Akers, Michael. 2005, Earnings Quality: It's Time to Measure and Report. The CPA Journal: 72, 11: 32-37.

Boediono, Gideon SB. Kualitas Laba: Study Pengaruh Mekanisme Corporate Governance dan Dampak Manajemen Laba dengan Menggunakan Analisis Jalur. Simposium Nasional Akuntansi VIII. Solo: 15-16 September 2005.

Dechow, P.M. 1995. Accounting Earnings and Cash Flows as Measures of Firm Performance: The Role of Accounting Accruals. Journal of Accounting and Economics 17, hlm. 3-42.

Dechow, P. M., R.G. Sloan and A.P. Sweeney. 1995. Detecting earnings Management. The Accounting Review, Hal 193-225.

Fala, Dwiyana A. S. 2007. Pengaruh Konservatisma Akuntansi terhadap Penilaian Ekuitas Perusahaan Dimoderasi Oleh Good Corporate Governance. Simposiun Nasional Akuntansi X Unhas Makassar.

Fitrijanti, Tettet dan Hartono, Jogiyanto. (2002). "Set Kesempatan Investasi: Konstruksi dan Analisis Hubungannya dengan Kebijakan Pendanaan dan Dividen”. Jurnal Riset Akuntansi Indonesia, Vol. 5, No. 1: 35 - 63. 
Francis, Jennifer, Dhananjay Nanda, Per Ollson. 2008. "Voluntary Disclosure, Earnings Quality and Cost of Capital". Journal of Accounting Research, Vol. 46, No. 1.

Gabrielsen, Gorm. Jeffrey D. Gramlich dan Thomas Plenborg. 2002. Managerial Ownership, Information Content of Earnings, and Discretionary Accruals in a Non-US Setting. Journal of Business Finance \& Accounting.29 (7) \& (8):967-988.

Gaver,Jennifer J.,dan Kenneth M.Gaver,1993,"Additional Evidence on the Association between the Investment Opportunity Set and Corporate Financing, Dividen, and Compensation Policies," Journal Of Accounting \&Economics , 16:125-160

Ghozali, Imam, 2013. Aplikasi Analisis Multivariat dengan Program IBM SPSS 21. Edisi 7, Penerbit Universitas Diponegoro, Semarang.

Givoly, Dan. and C. Hayn. 2000. The Changing Time-Series Properties of Earnings, Cash Flows and Accruals: Has Financial Reporting Become More Conservative. Journal of Accounting and Economics.29 (3), pp: 287-320.

Givoly, Dan. and C. Hayn. 2002. Rising Conservatism: Implication for Financial Analyst. Financial Analyst Journal Vol 58, 56-57.

Kallapur, Sanjay.and Trombley, Mark A. 1999. The Association between Investment Opportunity Set Proxies and Realized Growth, Journal of Bussiness Finance \& Accounting, 26:505-519.

Kazemi, Hossein, Hassan Hemmati, and Roghayah Faridvand. 2011. Investigating the Relationship Between Conservatism Accounting and Earnings Attributes. World Applied Sciences Journal, 12(9), pp: 1385-1396.

Lafond, Ryan, dan Watts, R.L. 2008. "The Information Role of Conservative Financial Statements", Social Science Research Network Electronic PaperCollection. http://papers.ssrn.com

La Porta, R., F.L. De-Silanes, A.Shleifer and R.Vishny. 2002. Investor Protection and Corporate Valuation. The Journal of Finance LVII (3).1147-1170

Lara, Juan M. G., Beatriz G. O., and Fernando Penalva. 2009. Accounting Conservatism and Corporate Governance. Review of Accounting Studies, 14(1), pp: 161-201.

Machfoedz, Mas'ud dan Suranta, Eddy. 2006. “Analisis Struktur Kepemilikan, Nilai Perusahaan, Investasi dan Ukuran Dewan Direksi”. Simposium Nasional Akuntansi VI. Surabaya. 
Mahadwartha, Putu Anom. 2003. "Predictability Power of Dividend Policy and Leverage Policy to Managerial Ownership in Indonesia: an Agency Theory Perspective". Jurnal Ekonomi dan Bisnis Indonesia, 18(3), hlm. 1-20.

Meeampol, Sasivimol, et al. 2013. The Relationship between Corporate Governance and Earnings Quality: A Case Study of Listed Companies in the Stock Exchange of Thailand (Set). Active Citizenship by Knowledge Management \& Innovation Learning, International Conference Zadar, Croatia.

Midiastuty, Pranata Puspa dan Mas' ud Machfoedz. 2003. “Analisis Hubungan Mekanisme Corporate Governance dan Indikasi Manajemen Laba". Simposium Nasional Akuntansi VI, Surabaya, 16-17 Oktober.

Morck, R. And A. Shleifer, and R.W. Vishny (1989), "Management Ownership and Market Valuation: An Empirical Analysis". Journal of Financial Economics, 20, p. 293-315.

Myers, S., 1977, "Determinant of Corporate Borrowing", Journal of Financial Economics. No. 5, 147-175.

Novianti, Rizky. 2010. Kajian Kualitas Laba pada Perusahaan Manufaktur yang Terdaftar di BEI. Accounting Analysis Journal Universitas Negeri Semarang.

Penman, S. and X.Zhang. 2002. Accounting Conservatism, Quality of earnings, Stock returns. The Accounting Review.

Sadidi, Mehdi, Ali Saghafi, and Shahin Ahmad. 2011. Accounting Conservatism and the Effect of Earning Quality on the Return of Assets and Stock Return. Journal of Accounting Knowledge.2 (6).

Schipper, Khaterine and Linda Vincent. 2003. "Earnings Quality”. Accounting Horizons, Vol.17. Supplemen.

Shen, Chung-Hua, \& Chih, Hsiang-Lin (2007). Earnings management and corporate governance in Asia's emerging markets. Journal Compilation, 15(5), 999-1021.

Siallagan, Hamonangan dan Mas'ud Machfoedz. 2006. "Mekanisme Corporate Governance, Kualitas Laba, dan Nilai Perusahaan”. Simposium Nasional Akuntansi IX. Padang.

Smith, C.W. Jr. dan R.L. Watts. 1992. "The Investment Opportunity Set and Corporate Financing, Dividend, and Compensation Policies". Journal of Financial Economics 32: 263--292. 
Sofian, Saudah, Siti Zaleha A.R., and Mohammad Ghorban Mehri. 2011. Conservatism of Earnings and Investor Protection. International Journal of Bussines and Social Science, 2(4).

Suaryana, A. (2005). Pengaruh Konservatisme Laba Terhadap Koefisien Respon Laba. Indonesia: Jurusan Akuntansi; Fakultas Ekonomi, Universitas Udayana.

Sutopo, Bambang. 2009. "Manajemen Laba dan Manfaat Kualitas Laba dalam Keputusan Investasi". Pidato Guru Besar.

Trianingsih, I. 2010. Pengaruh Konservatisme Akuntansi Terhadap Asimetri Informasi, Kualitas Laba dan Return Saham. Depok: Fakultas Ekonomi Universitas Indonesia.

Wah, Lai Kam. 2002. Investment Opportunity and Audit Quality. Journal of Accounting and Public Policy. No. 28, 33 - 50

Warianto, Paulina dan Rusiti, Ch. 2013. Pengaruh Ukuran Perusahaan, Struktur Modal, Likuiditas dan Investment Opportunity Set Terhadap Kualitas Laba pada Perusahaan Manifaktur yang Terdaftar di Bursa Efek Indonesia. EJournal Universitas Atma Jaya Yogyakarta.

Watts, R.L. 2003. Conservatism in Accounting Part I: Explanations and Implications.Working Paper. University of Rochester.

Yeo, Julia S.J., Aybuke Aurum, Meliha Handzic and Peter Parkin (2002). When Techonology is Mandatory-Factors Influcing User Satisfaction. Precedings of the International Conference on Computers in Education.

www.idx.co.id 